\title{
UNSUR-UNSUR RELIGIUS DALAM CERPEN “SEJUTA LANGKAH MENDAKI MIMPI” KARYA DIAN RAHAYU
}

\author{
Ila Nafilah \\ Program Studi Pendidikan Bahasa Indonesia, \\ Fakultas Bahasa dan Seni, Universitas Indraprasta PGRI \\ nafilah.salsabila@gmail.com
}

\begin{abstract}
Abstrak
Sastra merupakan karya imajinatif yang menggambarkan kehidupan bermasyarakat yang dapat dinikmati, dipahami, dan dapat dimanfaatkan oleh kalangan masyarakat. Salah satu penggambaran kehidupan dalam bermasyarakat, yaitu terdapatnya unsur-unsur religius sebagai pokok pembahasan yang sangat penting dalam bermasyarakat. Tujuan dari penelitian ini adalah mengetahui unsur religius yang digambarkan dalam Cerpen "Sejuta Langkah Mendaki Mimpi" karya Dian Rahayu. Penelitian ini menggunakan pendekatan deskriptif kualitatif yang mengedepankan kedalaman penghayatan terhadap interaksi antarkonsep yang sedang dikaji secara empiris dengan menggunakan kata-kata atau gambar. Penelitian dengan pendekatan kualitatif ini menggunakan metode analisis isi (content analysis). Metode penelitian yang digunakan untuk menganalisis cerpen ini adalah dengan menggunakan metode kualitatif yang memusatkan perhatian sematamata pada unsur-unsur instrinsik dengan mengkaji unsur religius yang berkaitan dengan unsur yang membangun karya sastra fiksi. Unsur-unsur religius di antaranya: akidah, syariah, akhlak. Teknik penelitian deskriptif yang dilakukan peneliti adalah teknik meneliti unsur religius. Teknik penelitian ini dapat dilakukan dengan membaca secara teliti unsur-unsur religius yang terdapat dalam sumber data, mengidentifikasi, mengklasifikasi, menganalisis, dan menyimpulkan data-data hasil penelitian mengenai unsur-unsur dalam cerpen "Sejuta Langkah Mendaki Mimpi” karya Dian Rahayu.
\end{abstract}

Kata Kunci: unsur-unsur religius dan cerpen

\begin{abstract}
Literature is an imaginative work that describes the life of society that can be enjoyed, understood, and can be utilized by the community. One of the depictions of life in the society that is the presence of religious elements that became the subject of a very important discussion in the community. The purpose of this research is to know the religious element which is described in the short story "Sejuta Langkah Mendaki Mimpi" by Dian Rahayu. This study uses a qualitative descriptive approach that emphasizes the depth of appreciation of the interaction between the concepts being studied empirically by using words or drawings. Research with this qualitative approach using content analysis method (content analysis). The research method used to analyze this short story is to use qualitative methods that focus solely on the intrinsic elements by studying the religious elements associated with the elements that build the fiction literary work. Religious elements include: aqidah, syariah, morals. Descriptive research techniques conducted by researchers is the technique of researching religious elements. This research technique can be done by reading carefully the religious elements contained in the data source, identifying, classifying, analyzing, and summarizing the research data about the elements in the short story "Sejuta Langkah Mendaki Mimpi " by Dian Rahayu.
\end{abstract}

Keywords: religious elements and short stories. 


\section{PENDAHULUAN}

Sejak ribuan tahun silam seni telah menyertai kehidupan umat manusia dari berbagai penjuru dunia, beraneka ragam permasalahan hidup dihadapi dengan mengungkapkannya melalui karya-karya seni. Melalui karya-karya seni pula permasalahan hidup manusia diungkapkan dengan memanfaatkan rasa estetis manusia. Karya sastra merupakan salah satu bidang yang dapat dimanfaatkan untuk memperkenalkan budaya bangsa sendiri kepada bangsa lain di dunia. Sebab karya sastra merupakan cerminan masyarakat bangsa tertentu dan sekaligus merupakan hasil penghayatan manusia yang paling dalam tentang kehidupan.

Memahami dan menikmati nilai yang terkandung dalam karya sastra atau lebih dikenal dengan apresiasi sastra tidak semudah memahami dan menikmati karya seni yang lainnya. Untuk memahami karya sastra diperlukan sekurang-kurangnya modal dasar berupa pengetahuan sastra dan sikap terhadap sastra, termasuk karya sastra yang berbentuk cerpen.

Maraknya kasus perkelahian antarpelajar di berbagai daerah di tanah air sehingga banyaknya korban yang meninggal. Selain itu, narkoba yang sudah masuk ke dalam dunia pendidikan, hubungan seks di luar nikah atau lawan jenis yang masih berstatus pelajar, serta kurangnya etika dalam bergaul, baik ucapan dan perbuatan saat di sekolah atau pun di luar sekolah. Hal ini adalah bagian dari krisis iman atau dapat disebut krisis moral pelajar. Keadaan ini tentunya sangat memprihatinkan bagi negeri ini. Oleh karena itu, sangat penting bagi pelajar untuk disirami atau dibina secara serius dari nilai-nilai religius.

Bertitik dari permasalahan tersebut, peneliti berupaya untuk menggali unsur-unsur religius dalam cerpen Sejuta Langkah Mendaki Mimpi karya Dian Rahayu. Melalui penelitian ini pembaca sastra diharapkan mengerti dan menambah wawasannya dalam hal mengkaji unsur religius yang ada dalam karya sastra berupa cerpen. Berdasarkan kondisi-kondisi yang terjadi ini peneliti tertarik untuk menganalisis isi cerpen tersebut dan memfokuskan pada unsur religiusnya.

\section{Tujuan Penelitian}

Berdasarkan rumusan masalah di atas, maka tujuan dilaksanakannya penelitian ini adalah: untuk memperoleh gambaran yang jelas tentang pengungkapan unsurunsur religius dalam cerpen "Sejuta Langkah Mendaki Mimpi karya Dian Rahayu."

\section{Tinjauan Pustaka}

\section{Hakikat Sastra}

Sumarno dan Saini (dalam Aswinarko dan Ahmad, 2013: 108) berpendapat bahwa 'Sastra adalah ungkapan pribadi manusia berupa pengalaman, perasaan, gagasan, semangat, keyakinan, dalam suatu bentuk gambaran konkret yang membangkitkan pesona dengan alatalat bahasa'. Oleh karena itu, sastra dapat berupa pengalaman dan bentuk gambaran konkret yang membangkitkan pesona dengan alatalat bahasa. Teeuw (2013: 20) mengemukakan bahwa sastra dalam bahasa Indonesia berasal dari bahasa Sansekerta, yaitu akar kata $h s-$, dalam kata kerja turunan berarti mengarahkan, mengajarkan, memberi petunjuk, atau instruksi. Akhiran -tra biasanya menunjukkan alat dan sarana. Oleh karena itu, sastra dapat bararti alat untuk mengajar, buku petunjuk atau pengajaran, dan sastra merupakan ajaran serta tulisan yang memiliki keindahan. 


\section{Hakikat Cerpen}

Cerpen atau dalam bahasa Inggrisnya dikenal dengan short story, merupakan satu karya sastra yang sering kita jumpai di berbagai media massa. Cerpen adalah salah satu karya sastra yang padat dan langsung pada tujuan ceritanya dan hanya menceritakan satu kejadian serta memiliki nilai-nilai kehidupan. Kosasih (2012: 34) berpendapat bahwa "cerita pendek (cerpen) merupakan cerita yang menurut wujud fisiknya berbentuk pendek. Ukuran panjang pendeknya suatu cerita memang relatif. Namun, pada umumnya cerita pendek merupakan cerita yang habis dibaca sekitar sepuluh menit atau setengah jam. Jumlah katanya sekitar 500-5000 kata. Karena itu, sering diungkapkan dengan cerita yang tepat dibaca dalam sekali duduk".

Zulfahnur (2011: 3.7-3.8) mengemukakan bahwa cerita pendek (cerpen) adalah cerita berbentuk prosa yang relatif pendek. Panjang pendeknya cerpen sebenarnya bersifat "relatif". Artinya, ukuran yang menjadi dasar pemikiran panjang pendeknya cerita, apabila cerita tersebut selesai dibaca hanya dalam waktu sekali duduk dalam waktu yang tentu saja relatif singkat.

\section{Ciri-ciri Khas Cerpen}

Ciri-ciri khas dari cerita pendek (cerpen) dapat dijabarkan sebagai berikut:

a. Ciri-ciri utama cerita pendek adalah: singkat, padu, dan insentif (brevity, unity, and intensity).

b. Unsur-unsur utama cerita pendek adalah: adegan tokoh, dan gerak (scene, character, and action).

c. Bahasa cerita pendek haruslah tajam, sugestif, dan menarik perhatian (incisive, suggestive, and alert) (Morris dalam Tarigan, 2011: 180).

d. Cerita pendek harus mengandung interpretasi pengarang tentang konsepsinya mengenai kehidupan, baik secara langsung maupun tidak langsung.

e. Sebuah cerita pendek harus menimbulkan efek dalam pikiran pembaca.

f. Cerita pendek harus menimbulkan perasaan pada pembaca bahwa jalan ceritalah yang pertama menarik perasaan dan baru kemudian menarik pikiran.

g. Cerita pendek mengandung detail-detail dan insiden-insiden yang dipilih dengan sengaja, dan yang bisa menimbulkan pertanyaan-pertanyaan dalam pikiran pembaca.

h. Dalam sebuah cerita pendek sebuah insiden yang terutama menguasai jalan cerita.

i. Cerita pendek harus mempunyai seorang pelaku utama.

j. Cerita pendek harus mempunyai satu efek atau kesan yang menarik (Lubis dalam Tarigan, 2011: 180).

k. Cerita pendek bergantung pada (satu) situasi.

1. Cerita pendek memberikan impresi tunggal.

m. Cerita pendek memberikan suatu kebulatan efek.

n. Cerita pendek menyajikan satu emosi (Brooks dalam Tarigan, 2011: 180).

o. Jumlah kata-kata yang terdapat dalam cerita pendek biasanya di bawah 10.000 kata, tidak boleh lebih dari 10.000 kata (atau kirakira 33 halaman kuarto spasi rangkap) (Notosusanto dalam Tarigan, 2011: 180). 


\section{Hakikat Religius}

Istilah religius menurut Departemen Pendidikan Indonesia, Kamus Besar Bahasa Indonesia (2008: 1159) mengandung arti bersifat religi; bersifat keagamaan; yang bersangkutan paut dengan religi. Ali (2013: 37) berpendapat bahwa "istilah religius terjemah religion yang berasal dari kata relegere dalam bahasa Latin artinya berpegang kepada norma-norma." Istilah religion, sekarang di Indonesiakan menjadi religi. Menurutnya perkataan religi berasal dari bahasa latin itu erat hubungannya dengan sistem dan ruang lingkup agama Nasrani. Bagi orang Eropa religion hanyalah mengatur hubungan tetap (vertikal) antara manusia dengan Tuhan saja.

Menurut Mangunwijaya

(dalam Lathief, 2008: 175) mengemukakan bahwa "religius berasal dari bahasa latin relego, dimaksudkan dengan menimbang kembali atau prihatin tentang suatu hal." Seorang religius dapat diartikan sebagai manusia yang berarti, yang berhati nurani serius, saleh, teliti, dan penuh pertimbangan spiritual. Istilah religius berbeda dengan agama, menurutnya bahwa religius lebih melihat pada aspek lubuk hati getaran jiwa yang mencakup totalitas ke dalam pribadi setiap individu, sedangkan agama lebih menunjukan pada kelembagaan kebaktian kepada Tuhan serta peraturan hukum yang ada di dalamnya.

Sastra religius mempunyai hubungan yang sangat erat. Dalam hubungan sastra dan religius dapat memaparkan segala bentuk aturan atau kaidah-kaidah serta norma kehidupan sentuhan seni dari segi bahasa maupun tulisannya. Dengan kata lain, ajaran nilai agama yang terdapat dalam karya sastra mengandung unsur seni yang bernilai religius.

Jadi, dapat disimpulkan dari beberapa uraian religius tersebut bahwa istilah religius adalah suatu keimanan, keyakinan, kepercayaan yang ada pada hati, jiwa setiap individu terhadap ajaran-ajaran agamanya.

Nilai religius atau keagamaan adalah nilai yang berhubungan dengan agama, keimanan seseorang dan tanggapan seseorang terhadap nilai yang diyakini serta tindakan manusia yang memancarkan keimanan kepada Tuhan Yang Maha Esa (Jauhari, 2010: 27)

Ali (2013: 133) menjelaskan bahwa dalam agama Islam memiliki tiga kerangka dasar, yaitu 1) Akidah, 2) Syariah, dan 3) Akhlak. Tiga kerangka dasar tersebut yang akan menjadi bagian penelitian dalam penulisan karya ilmiah ini. Kerangka dasar dalam Islam merupakan bagian yang paling penting bagi seseorang dalam memeluk agamanya. Sebab dengan mengetahui kerangka dan mengaplikasikan dalam kehidupan sehari-hari, maka seseorang layak menyandang manusia religius. Berikut ini uraian mengenai ketiga kerangka dasar tersebut.

\section{a. Akidah}

Akidah berasal dari bahasa Arab. Akidah berakar dari kata aqida $+y a$ 'qudu-aqdan. Akidah menurut ilmu yang menyelidiki asal-usul kata serta perubahanperubahan dalam bentuk dan makna (etimologi) adalah ikatan, sangkutan (Ali, 2013: 133). Menurut istilah (terminalogi) akidah adalah iman, keyakinan, sedangkan Hadnan (2010: 22) berpendapat bahwa "akidah 
adalah kepercayaan sepenuh hati terhadap sesuatu yang diyakini kebenarannya sehingga tercermin dalam tingkah laku dan perbuatan dalam kehidupan sehari-hari." Akidah merupakan dasar keyakinan dan komitmen tentang keesaan Allah Swt. yang mengandung konsekuensi ketauhidan dalam menunaikan segala interaksi kehidupan. Istilah lain menyebutkan bahwa akidah itu membenarkan dengan hati, mengucapkan dengan lisan, dan mempraktikkan dalam perbuatan atau tindakan. Jadi, dapat disimpulkan bahwa akidah adalah apa yang telah menjadi ketetapan, keyakinan, dan kepercayaan di dalam hati seseorang secara pasti, baik itu benar maupun salah.

\section{b. Syariah}

Makna asal kata "syariah" adalah jalan ke sumber (mata) air. Istilah syariah dalam bahasa Arab berasal dari kata syari', secara harfiah berarti jalan yang harus dilalui oleh setiap muslim (Ali, 2013: 235). Pengertian syariah secara bahasa berarti jalan, peraturan, undang-undang tentang suatu perbuatan atau menggariskan suatu peraturan maupun pedoman. Syariah secara leksikal berarti jalan menuju perhimpunan air untuk diminum manusia juga binatang peliharaan. Dari makna kebahasaan ini orang Arab menggunakannya sebagai ungkapan tentang jalan lurus yang dipedomani bersama. Syariah mengatur hidup manusia sebagai individu, yaitu hamba Allah yang harus taat, tunduk, dan patuh kepada-Nya (Zawawi, 2008: 88). Ketaatan, ketundukan, dan kepatuhan kepada Allah dibuktikan dalam bentuk pelaksanaan ibadah yang tata caranya diatur sedemikian rupa oleh syariat Islam.

Berdasarkan definisi syariah tersebut, maka dapat disimpulkan bahwa syariah adalah undang-undang, pedoman, atau ketetapan dari Tuhan yang ditunjukan pada hamba-Nya untuk dilaksanakan dengan sebaik-baiknya guna meraih kehidupan yang tenteram.

\section{c. Akhlak}

Akhlak berasal dari kata khuluk yang berarti perangai, sikap, perilaku, watak, budi pekerti. Akhlak pada dasarnya adalah sikap yang melekat pada diri seseorang secara spontan diwujudkan dalam tingkah laku atau perbuatan (Azra dkk., 2002: 203). Jika perilaku yang melekat itu buruk maka disebut akhlak yang buruk atau akhlak mazmumah. Sebaliknya, jika perilaku itu baik maka disebut akhlak mahmudah. Menurut Zawawi dkk. (2008: 117) berpendapat bahwa akhlak adalah perbuatan manusia yang bersumber dari dorongan jiwanya. Gerakan reflek, denyut jantung dan kedipan mata tidak dapat disebut akhlak, karena gerakan itu tidak diperintah oleh unsur kejiwaan.

Akhlak dapat digolongkan menjadi tiga, yaitu 1) akhlak terhadap Allah, 2) akhlak terhadap manusia, 3) akhlak terhadap sosial atau lingkungan, (Azra dkk., 2002: 205). 1) Berakhlak kepada Allah dilakukan melalui media komunikasi, antara lain melalui kegiatan ibadah, seperti salat, 
mengaji, berzikir, berdoa, tawakal, atau berserah diri; 2) akhlak kepada manusia dapat dibedakan sebagai berikut: a) Akhlak kepada diri sendiri; b) Akhlak kepada keluarga; c) Akhlak kepada ibu dan bapak; d) Akhlak kepada guru. 3) Akhlak terhadap lingkungan atau sosial, adalah menjadi dan mengembangkan hubungan yang harmonis dengan alam sekitarnya, bukan dengan hanya manusia saja, tetapi juga dengan alam tempat manusia itu tinggal, misalnya memakmurkan alam, hutan, laut, juga memelihara hubungan antarmasyarakat dan tetangga.

\section{METODE PENELITIAN}

Penelitian ini menggunakan pendekatan deskriptif kualitatif yang mengedepankan kedalaman penghayatan terhadap interaksi antarkonsep yang sedang dikaji secara empiris dengan menggunakan kata-kata atau gambar.

Penelitian dengan pendekatan kualitatif ini menggunakan metode analisis isi (content analysis). Analisis isi ini digunakan dalam pencarian fakta dengan interpretasi data berupa unsur religius yang berasal dari cerpen "Sejuta Langkah Mendaki Mimpi" karya Dian Rahayu. Analisis yang dilakukan adalah analisis terhadap unsur religius.

Teknik penelitian deskriptif yang dilakukan peneliti adalah teknik meneliti unsur religius. Teknik penelitian ini dapat dilakukan dengan membaca secara teliti unsur-unsur religius yang terdapat dalam sumber data, mengidentifikasi, mengklasifikasi, menganalisis, dan menyimpulkan data-data hasil penelitian mengenai unsur-unsur dalam cerpen. Jadi, analisis isi adalah penelitian yang berusaha menganalisis dokumen untuk mengetahui isi dan makna yang terkandung dalam dokumen tersebut.

\section{Subjek dan Fokus Penelitian}

Subjek penelitian adalah data yang akan diteliti atau dianalisis. Dalam penelitian ini yang akan dijadikan subjek penelitian adalah unsur-unsur religius yang berasal dari cerpen "Sejuta Langkah Mendaki Mimpi" karya Dian Rahayu. Sehubungan dengan tujuan khusus penelitian, maka penelitian memfokuskan penelitian ini pada unsurunsur religius. Subfokus dalam penelitian ini terdiri dari tiga unsur, yaitu akidah, syariah, dan akhlak.

\section{HASIL DAN PEMBAHASAN}

\section{Deskripsi Informasi Penelitian}

Deskripsi informasi penelitian adalah gambaran mengenai data yang diteliti. Data unsur-unsur religius yang diteliti bersumber dari cerpen "Sejuta Langkah Mendaki Mimpi" karya Dian Rahayu berdasarkan unsur akidah, syariah, dan akhlak.

Sinopsis cerpen "Sejuta Langkah Mendaki Mimpi" karya Dian Rahayu akan dijabarkan sebagai berikut: Cerita ini mengisahkan tentang sepasang mudamudi yang saat itu memunyai keinginan untuk dapat mendaki puncak gunung Cikuray yang terletak di desa Cilawu, kota Garut, Jawa Barat. Setelah mereka mendapat restu dari kedua orang tua, mereka pun berangkat mendaki puncak gunung Cikuray. Perjalanan mereka saat mendaki gunung Cikuray tak semulus harapan, saat itu cuaca cukup ekstrim mengakibatkan perjalanan untuk mencapai puncak memakan waktu yang lebih lambat. Raisa hampir saja menyerah, dirinya merasa perlu untuk beristirahat lebih cepat dan meminta pendakian dilanjutkan esok saja, Raisa merasa was-was dengan cuaca saat itu ditambah waktu sudah malam. Berbeda 
dengan Reza yang sangat bersikeras ingin tetap melanjutkan pendakian sampai ke pos terakhir. Raisa menghilangkan semua kegelisahan dengan menanamkan pikiran, bahwa mendaki gunung bukan soal kekuatan tapi mental pemberani yang harus diteguhkan. Pada malam itu mereka berdua pun tetap melanjutkan pendakian hingga pos terakhir. Malam pun berganti pagi, mereka pun menikmati suguhan pemandangan yang sangat indah sebagai bayaran atas perjuangan mereka mendaki puncak gunung Cikuray. Mereka pun akhirnya sampai pada puncak gunung Cikuray, gunung tertinggi keempat di Jawa Barat. Setiap kali kita mempunyai mimpi, keinginan atau cita-cita maka simpanlah di depan kening, agar ia menempel, biarkan ia menggantung, mengambang lima $\mathrm{cm}$ di depan kening kita sehingga kita dapat mengingat bahwa apa pun hambatannya percayalah jika kita mampu dan berjanji untuk tidak mudah menyerah.

\section{Analisis Data}

\section{1) Akidah}

Akidah merupakan dasar keyakinan dan komitmen tentang keesaan Allah Swt. yang mengandung konsekuensi ketauhidan dalam menunaikan segala interaksi kehidupan. Pemeran/ tokoh dalam cerpen ini, yaitu Raisa, Reza, ibu Raisa, dan ayah Raisa, memiliki nilai religius di dalam kehidupan mereka sehari-hari. Mereka percaya dan meyakini bahwa Allah Swt., Sang Maha Pencipta yang menjadikan mereka sebagai manusia yang lebih banyak bersyukur dalam menjalani kehidupan. Unsur religius yang pertama, yaitu akidah, dapat dijabarkan dalam kutipan di bawah ini:

"Keindahan yang memesona membuat rasa syukur menyeruak saat tersadar telah lahir di dunia" (SLMM: 1).

Kutipan di atas menjelaskan tentang rasa syukur yang disampaikan penulis karena telah dilahirkan ke dunia yang amat indah ini.

Kutipan selanjutnya yang menggambarkan unsur religius berupa akidah mengenai pesan ayah Raisa ketika hendak pergi ke puncak gunung Cikuray, Jawa Barat. Kutipannya dapat dilihat di bawah ini:

"Hati-hati di sana, jangan nakal, banyak-banyak ingat sama Allah, dan jangan lalaikan salat Rai!" Pesan ayah yang terus berulangulang sejak kemarin"(SLMM: 3).

\section{2) Syariah}

Syariah merupakan undang-undang, pedoman, atau ketetapan dari Allah yang ditunjukkan pada hamba-Nya untuk dilaksanakan dengan sebaikbaiknya. Unsur religius yang berhubungan dengan syariah dapat dilihat dalam kutipan-kutipan di bawah ini:

"Seperti waktu melesat dengan kecepatan tinggi, suara adzan berkumandang terdengar syahdu di sepanjang jalan” (SLMM: 6).

"Kita salat di dekat pom bensin depan aja yah Rai?" Kata Reza dengan jelas" (SLMM: 6).

"Masih jauh enggak? Udah mau setengah 6 tau, malu kan kalau kesiangan salatnya." Jawabku penuh tanya" (SLMM: 7). 
... "Beberapa menit kemudian sampailah kita di sebuah masjid yang bernama Baiturrahman ... Reza menghentikan motornya tepat di depan tempat untuk berwudhu ... Kita sama-sama segera mengambil wudhu dan salat. Di dalam masjid terdapat dua orang pria dewasa yang sedang sibuk melantunkan ayat-ayat suci Al-Qur'an. Setelah selesai salat aku begitu enggan untuk segera pergi dari tempat ini, tubuhku terasa lemas, seperti manusia yang belum makan seharian ..." (SLMM: 7).

\section{3) Akhlak}

Akhlak merupakan perangai, sikap, perilaku, watak, dan budi pekerti yang melekat pada diri seseorang. Akhlak dapat digolongkan menjadi tiga, yakni: 1) akhlak terhadap Allah; 2) akhlak terhadap manusia; 3) akhlak terhadap manusia; dan 3) akhlak terhadap sosial atau lingkungan. Unsur religius yang berhubungan dengan akhlak dapat dilihat dalam kutipan-kutipan cerpen di bawah ini:

a) Akhlak terhadap Allah

Akhlak terhadap Allah meliputi salat, mengaji, berzikir, berdoa, tawakal atau berserah diri. Di bawah ini merupakan kutipankutipan yang menunjukkan akhlak terhadap Allah:

"Iya udah, ayo naik. Sebelum berangkat kita berdoa dulu. Bismillah berangkat." Jawab Reza dengan penuh semangat" (SLMM: 4).

"Amin. Kamu tenang aja Rai enggak usah panik, kita berdoa aja semoga hujan dan badai cepet berhenti." Kata Reza yang berusaha menenangkan keadaan" (SLMM: 16).

b) Akhlak terhadap manusia

Akhlak terhadap manusia meliputi: akhlak kepada diri sendiri, akhlak kepada keluarga, akhlak kepada ibu dan bapak, dan akhlak kepada guru.

Kutipan yang berkaitan dengan akhlak kepada diri sendiri di antaranya terdapat dalam kutipan-kutipan sebagai berikut:

... "Aku akan hati-hati dan ingat pesan kalian, nanti kalau sudah sampai aku pasti kabari." Jawab ku penuh semangat untuk meyakinkan perasaan mereka bahwa aku pasti akan pulang kembali dengan selamat" (SLMM: 3).

Kutipan di atas menggambarkan mengenai akhlak kepada diri sendiri yang menyatakan rasa percaya diri Raisa.

... "Heran dengan lelaki satu ini, sudah ku bilang kalau datang ke rumah hendaklah bersopan santun dengan tanya sapa, agar ayah dan ibu tidak begitu khawatir telah mengizinkan anak gadisnya berteman dengannya. Tapi pemuda ini nampaknya selalu lupa dan harus diingatkan" (SLMM: 3-4).

c) Akhlak terhadap sosial atau lingkungan 
Akhlak terhadap sosial atau lingkungan digambarkan dengan hubungan yang harmonis antara manusia dengan alam sekitarnya juga memelihara hubungan antarmasyarakat dan tetangga. Berikut ini akan dipaparkan kutipan-kutipan mengenai akhlak terhadap sosial atau lingkungan.

"Pagi di musim pengugur, matahari kembali bersinar dari timur. Semburat jingga seperti senja mulai nampak mewarnai ruang luas yang terbentang di atas bumi, tempat beradanya bulan, bintang, matahari dan planet-planet yang lain berdiam. Terngiang indah semesta dunia yang bernama bumi planet semua manusia, hewan, dan tumbuhan yang hidup, bergerak, dan bekerja sebagaimana mestinya"... (SLMM: 1).

... "Dari luar nampak kedamaian, lapangan tempat terparkirnya kendaraan terlihat bersih dan asri oleh pepohonan dan bunga-bunga yang tertanam rapih di pelataran masjid ini"... (SLMM: 7).

... "Para warga memberikan jasa ojek yang biayanya cukup mahal di kantong mahasiswa seperti kami, yaitu $R p .70 .000$ untuk pulang pergi. Kami melakukan negosiasi namun tetap tidak memberikan untuk kami.

\begin{abstract}
Akhirnya aku meminta kepada mereka untuk mengantarkan kami menggunakan mobil dengan tarif Rp. 130.000 untuk pulang pergi perjalanan. Akhirnya mereka pun menyetujui kemauan ku, mungkin mereka melihat aku seorang perempuan dan membawa peralatan yang cukup berat" ... (SLMM: 12).
\end{abstract}

\section{Pembahasan dan Deskripsi Hasil Analisis}

Pembahasan dan deskripsi hasil analisis merupakan rekapitulasi data unsur-unsur religius yang peneliti temukan dari sumber data berupa cerpen "Sejuta Langkah Mendaki Mimpi" karya Dian Rahayu. Total keseluruhan unsur-unsur religius berjumlah 54 dengan subfokus akidah, syariah, dan akhlak. Data keseluruhan tersebut terdiri dari 7 atau $13 \%$ unsur religius dengan subfokus akidah, 8 atau $15 \%$ dari subfokus syariah, dan 39 atau $72 \%$ dari subfokus akhlak.

Berdasarkan data unsur-unsur religius, ditemukan data yang sama antara unsur religius akidah dan unsur religius akhlak, yaitu tiga buah data, sedangkan data yang sama antara unsur religius syariah dan unsur religius akhlak, yaitu dua buah data.

Berdasarkan pembahasan dan deskripsi di atas, dapat diketahui bahwa jumlah unsur religius dengan subfokus akhlak lebih banyak dibandingkan dengan unsur religius dengan subfokus akidah dan syariah.

\section{SIMPULAN}

Setelah melakukakan penelitian dengan meninjau beberapa pandangan penghayatan tentang unsur-unsur 
religius yang terdapat dalam cerpen "Sejuta Langkah Mendaki Mimpi ” karya Dian Rahayu maka dapat disimpulkan sebagai berikut: 1) ditemukan data sebanyak 54 buah unsur-unsur religius di antaranya akidah, syariah, dan akhlak; 2) memiliki kandungan unsur religius yang terdiri dari aspek akidah sebanyak 7 temuan atau $13 \%$, aspek syariah 8 temuan atau $15 \%$, dan aspek akhlak sebanyak 39 temuan atau $72 \%$, dari ketiga aspek tersebut yang paling besar proposisinya, yaitu aspek akhlak; 3) khususnya unsur-unsur religius sehingga dapat memberikan inspirasi bagi pembaca atau penikmat sastra, khususnya seluruh lapisan masyarakat dan diterapkan dalam kehidupan seharihari.

\section{DAFTAR PUSTAKA}

Ali, M. D. (2013). Pendidikan Agama Islam. Jakarta: PT Raja Grafindo Persada.

Aswinarko dan Ahmad. (2013). Pengantar Sosiologi Sastra. Jakarta: Unindra Press.

Azra, A. dkk. (2002). Buku Teks Pendidikan Agama Islam Pada Perguruan Tinggi Umum. Departemen Agama RI.

Departemen Pendidikan Indonesia (2008). Kamus Besar Bahasa
Indonesia. Jakarta: Balai Pustaka.

Hadnan, M. (2010). Ayo Mengkaji Alquran dan Hadist. Jakarta: PT Gramedia Pustaka.

Jauhari, H. (2010). Cara Memahami Nilai Religius dalam Karya Sastra. Bandung: Arfino Raya.

Kosasih, E. (2012). Dasar-dasar Keterampilan Bersastra. Bandung: Yrama Widya.

Lathief, S. I. (2008). Sastra: Eksistensialisme-Mistisme Religius. Lamongan: Pustaka Ilalang.

Tarigan, H. G. (2011). Prinsip-Prinsip Dasar Sastra. Bandung: Angkasa.

Teeuw, A. (2013). Sastra dan Ilmu Sastra. Cet IV. Jakarta: Pustaka Jaya.

Zawawi, S. dkk. (2008). Pendidikan Agama Islam. Jakarta: Universitas Tri Sakti Jakarta.

Zulfahnur Z. F. (2011). Teori Sastra. Jakarta: Universitas Terbuka. 